\title{
The existence of Reba
}

\author{
Bertolomeus Loji Sua \\ Universitas Sebelas Maret, Surakarta - Indonesia, (imdibertho@gmail.com)
}

\begin{abstract}
This article explains about the existence of 'Reba' as a culture in the midst of easy and instant modernization, especially in getting information supported by modern technology. So far Bajawa people still maintain and revive 'Reba' so that the culture of 'Reba' still shows its existence in the middle of the current globalization and modernization. 'Reba' is an unifying symbol for generations of Bajawa people that cannot be replaced with other cultures because the culture of 'Reba' has history and philosophical value that are only understood by Bajawa people.The culture of 'Reba' is not only for an annual celebration of gratitude, but also as as a venue for family gathering coming from distant places. The end of this article will also explain about moral values of the culture of 'Reba' so that 'Reba' can be maintained as a celebration of gratitude toward ancestors in the midst of modernization.
\end{abstract}

Keywords: reba, communication, community, modernization.

\section{Introduction}

Globalization era gives a big influence for the existence of local cultural elements which caused in the decreasing of the value and function from a culture (Sudarma, 2015: 182).It becomes a problem and homework for the community and future generations in order to maintain the existence of local culture in the middle of globalization and modernization. The erosion of local culture is not impossible for Ngada people, especially in reba culture but until now reba still shows its existence in the society of the midst modernization stream.Basically, reba becomes a symbol of Ngada culture, as a symbol of thanksgiving for fortune or harvest for a year. For Ngada people, reba is not only as an annual ritual but also become a symbol of gratitude to Tuah and the ancestors, the symbol of unifying family, as deliberation media and also reba teachs Ngada people about the value of unity and moral education value.Explicitly, reba does not not directly teach about moral education, but implicitly there are moral values that are directly understood and undertaken by Ngada society. In this paper,it will be explained about the existence of reba culture in the middle of modernization with the rapid development of technology and information. Why do the reba survive, if only as a symbol of thanksgiving and media persuasion and family deliberation on plans in the new year. This paper will explore in depth about the existence of reba in the midst of rapid and instantaneous modern modernization.

Every society has different culture, especially in Indonesia which contains society with high level of cultural pluralism. In a culture, there are classifications of the environment which is a series of system that integrated structurally and psychological (Iriani, 2013: 4). Meanwhile, according to Lubis 
(1993: 166) structurally integrated culture through the functions of its institutions, it is by the existence of every institution roles in the culture that is played in relation to other regulations of the culture, which applies thoroughly. Culture becomes a symbol and a characteristic that describes and reflects a particular society. The system of values, symbols and cultures are an integral unity, one another connected and direct in concrete society life .Every culture possesses symbols and values about the relationship between man and God, human with the ancestors, and human relationships with the natural environment. All cultural activities are built and maintained through rituals formed by the community, one of them is Ngada, Flores, East Nusa Tenggara (NTT) with Reba culture that is owned and lived and continue to be treated until now. Some cultures are possessed by the community that experience a shift or change caused by the strong increasingly of modernization especially in obtaining information. Despite the ever-expanding modernization and technology that facilitate the acquisition of information, Ngada society still maintain and switch on reba, so the culture of reba still shows the existence in the middle of the current modernization and globalization era. Modernization is still accepted by the Ngada society but that is not breaking down the reba as a medium of gratitude and meeting among Ngada people.

Basically, The culture of reba is a hereditary culture owned by Ngada people as a thanksgiving to God and the ancestors which held annually. Besides as a thanksgiving, reba also become a unifying medium of large families who come from various regions or overseas. Deliberation in the family on the night of reba becomes an integral part. This deliberation is meant to discuss the plan of the extended family in the new year after the reba. As a culture, reba contains its own moral and educational values, the moral value will be presented at the end as a discussion material in relation to the existence of reba in the midst of the current modernization.

In this paper, there are some important things that become research questions ;

1. What is the culture of Reba?

2. How is the existence of Reba culture in the midst of the Modernization development?

3. What are the values and messages of moral education in the Reba culture?

This research aims to provide an explanation to know deeply about reba culture in Ngada society, and explain the existence of reba as a culture in the midst of modernization with the development of information technology. Another purpose of giving an understanding to the audience or readers about moral education values contained in the reba implied to the public.

\section{Method}

This study uses qualitative research methology, with in-depth interviews. In addition through indepth interviews the author also uses the method of literature by examining some library sources that support research writer. Data collection techniques is the most strategic step in the research, because the main purpose of the research is obtaining data (Sugiyono, 2013: 62).

\section{Result and Discussion}

Ngada people are one of the tribes that inhabit the central of Flores islands. Ngada society has a different cultural style with other communities on Flores. The differences can be seen from the language used, custom rituals (one of them reba), custom clothes motifs, until the adopted marriage system . Ngada people adheres to matrilinear marriage system, this is different from the marriage system adopted by other communities on the Flores. In general, Floresian society embraces patrilinear marriage system, except for Ngada people.

One of the culture element is tradition, which has been inherited by the community for generations (Putra, 2015: 218). The reba culture is owned by the Ngada people, it is a cultural heritage preserved and lived up to now. Reba has a meaning as a symbol of thanksgiving of Ngada people to God or Ngada people call it 'Dewa Zeta' and to the ancestors or 'Ebu Nusi'. Both are 
believed by the Ngada people as the origin of creation and their presence on earth.Besides that, reba becomes the media of Ngada people's gratitude for the harvest, fortune, and blessings gained during the year. Therefore, reba celebration is also called as the celebration of Ngada new year. Thus, every year Ngada people from each tribe celebrate the new year and the celebration is known as reba as Ngada traditional year celebration. Traditional word can be interpreted as: 1) Hereditary (about life view, belief, art, dance, ceremony, etc.); 2) Based on custom ; upacafa; ceremonies (according to) custom (Poewardarminta, 2007: 1293).

Modernization affects the development of society from time to time and continues to experience both the change in terms of technology and information to culture. Modernization is a change, but the change has both positive and negative sides. The positive side of modernization can be seen from the development of technology, openness of society, while the negatif side of modernization is the change and shift of culture and the pattern of society life with the perpetual values and social norms.

It cannot be denied that the modernization with various technological advances and the development of popular culture also colored Ngada society life in particular Ngada local society. Ngada people openly accept and keep up with the times and popular culture today, but Ngada society retains local culture and wisdom from its authenticity, such as reba culture.

Along with the era development known as modernization, reba live in the midst of the changing times. Some of the authors findings in the field show that reba is not only an annual ceremony, but also reba become the symbol and identity of Ngada people.

Reba is a thanksgiving ceremony of Ngada people for the blessings and the harvests given. The gratitude is addressed to God and the ancestors. This annual celebration as well as a celebration of gratitude also as a gathering of the entire family of Ngada tribes from various corners of the country.

Previously, a Dutch missionary has done research related to the culture of Ngada people, one of them is reba.

Paul Arndt who conducted research at Ngada in the 1930s until the 1960s tried to find the original meaning of the word of reba. Although, he could not find the word of reba, he raised the hypothesis with respect to the word of reba. He tried to connect the word to the weather in reba (January). At that time, Ngada region gets high rainfall accompanied by wind or storm. As a result the trees can fall, the plants fall to the ground and damaged, and various other damages. From these circumstances, Arnd found two words of Malay language that seems similar to the word of reba that are rebah and ribut. These two words can be used to describe the situation in January. then these two words change into reba. Both consonants $h$ and $t$ disappear because Ngada language generally has syllables ending in vowels. Nevertheless, Arndt admits that this hypothesis does not work to find out where the word of reba came from (Dhogo, 2009: 12).

Ngada people define the term of reba to express the following two things; first, as the name of the moon and second, as the name of the opening ceremony of the new year. First, the people of Ngada have known the calculation of its own year calenderium. there are 12 names of months commonly known by Ngada people, starting with a month named reba (Dhogo, 2009: 10). Second, reba as the celebration of the new year. Generally, this celebration takes place from late November or early December to late February. This celebration became a meaningful celebration because Ngada people expressed their gratitude for the grace of their lives in the past year and at the same time ask the blessings for the life journey in the new year (Ghodo, 2009: 10).

The development of modernization can not be denied by the society that is very influential in the order of society life both negative and positive. Modernization is opened to the entering of external influences on all life aspects of the nation such as influence of culture. According Nurcholish Madjid, the meaning of modernization is almost identical to the meaning of rationalization, they are the process of overhauling patterns of thinking and working procedures that are not rational and replace 
it with a rational thinking and new rules of work. It is done by using the discovery of the latest human in the field of science (Madjid, 1997: 172). In the midst of the modernization of reba still exist its existence as a wise and local culture. Wisdom and local in the sense that the reba is not biased against technological developments that also exist with society.

If it is associated with modernization in its rational sense in order to overhaul the old irrational workings become more rational so reba should be changed. Why it should be done; first, Ngada people in general is a society that has religion and belief (catholic), but in reba also takes part in the gratitude expression for Ngada people. Second, in reba culture as ceremony of thanksgiving Ngada society can be said the experience of a waste especially in preparing reba. The preparation are food (rice and meat) and beverage(tuak) for all people who visiting the village following reba activity.

Reviewed from both of the above explanation then reba should be experienced a shift from local to global. From the wider local to the more modern and economical, the society retains the reba as a sacred culture. Reba as a media of thanksgiving to God and the ancestors in different ways.

There are several reasons why reba is not only an annual ceremony but also a symbol and identity of Ngada people.

1. Basically, reba is a thanksgiving ceremony to God and the ancestors for the blessings and fortune that are experienced by everyone Ngada.

2. In the reba, Ngada people are reminded of the historical of Ngada people origin until they reached the land of Flores. Ngada people in poetry singing at the time of reba often sing or poetry about the journey of the ancestors who according to their belief comes from the interior of Java or in Ngada language called 'Java One'.

3. Reba becomes a unifying symbol for all of Ngada people especially family.

4. Reba becomes the media of deliberation and consensus in each family over the plan in the new year (after reba).

Each culture has its own moral values and education. Through reba culture, Ngada people are taught about the values of brotherhood, education, and moral values. Therefore, the existence of reba in the midst of modernization is not merely as an annual ceremony, but also as a symbol of a society containing educational and moral values.

As a culture certainly can not be separated from the education value. Education is the process of changing the attitude and behavior of a person or group in mature effort through teaching and training efforts (KBBI, 1993: 232).Education in reba culture is different from formal education in general. In reba culture, the education value is not conveyed directly, but more to the attitudes and behavior of the community during reba.The value of education contained in reba is more to character education. The community is taught to respect each other and uphold the brotherhood, for example by gathering together and listening to traditional advices.In addition, the sense of companionship is shown by sharing. Every tribe who celebrating reba is obliged to invite guests from any community to share in the day of reba by eating and drinking together.

Besides the education value, reba also contains moral values in it. Licona, in the Sudikan (2013: 24) quoted Son (2015: 219), argues that there are two values in the main moral that are universal. Two values that are universal are, 1) respect, and 2) responsible. Moral values in reba are presented in poetry or poems custom that teach respect and responsibility, which is sung in the form of singing at the time of doing Ja'i dance. Ja'i dance becomes a typical dance of Ngada people especially in reba celebration. In the dance of Ja'i, many cultural poems contain a moral message in it, such as the following verse: 
Ma'e ngazo-ngazo,

Jangan busukuan nama sesama,// Do not book fellow names,

sabu la'a wae, toke ma'e deke,

Ketika mengambil bambu air, bambu jangan kau tegakan// When taking water, bamboo do not stand,

Sabu dua wi uma, nuka wi sa'o

Ketika pergi ke ladang, atau pulang ke rumah// When going to the fields, or going home

Wai kisa zala, go ngaza ngata, mae ngazo-ngazo,

Serta dalam perjalanan, nama orang, jangan kau burukan// And on the way, the name of the person, do not you hunted

Sabu da meda, ne'e bu'e woe hoga woe,

Bila engkau duduk, bersama sahabat-sahabat,// When you sit down, with your friends,

Ma'e ngazo-ngazo go ngaza ngata.

Jangan memburukan nama sesama// Do not ruin your fellow names.

Fai ngata da ba'i,

Istri orang jangan digoda,// Wife of people do not be tempted,

kiri tore da modhe,

gadis sopan adalah baik.// polite girl is good.

Reta todo da molo.

Gadis yang rambutnya belum tercukur// The girl whose hair is not yet shaved

Go wiwi bhoko-bhoko, go lema meta-meta,

Jagalah mulutmu, jagalah lidahmu// Take care of your mouth, keep your tongue

La'a zala ma'e nugu nanga,

Dalam perjalanan jangan sembarang bicara,// On the way do not just talk,

Page wesa, mae ngazo-ngazo,

Bila bepergian, jangan sembaran membicarakan nama orang,// When traveling, do not talk

about people's names,

La'a ghoa-ghoa,

Berjalanlah dengan tenang,// Walk calmly,

Ngia kisa uma, page ghera-ghera lea ngia ngora.

Di tengah ladang berjalanlah lurus-lurus di tengah kebun.//n the middle of the field walk straight in the middle of the garden.

Lau mai moli bata,

Di jalan masuk kampung//At the entrance to the village

Miu da sabu mogo-mogo,

Kamu saling jumpa,// You meet each other,

Da mua sama-sama,

Kamu saling bertemu,// You meet each other,

Wi papa tana, wi papa pita,

Saling bertanya, saling mencari,// Asking each other, searching each other,

Miu nenga ghili woe.

Lalu bersatu bersaudara.// Then united siblings.

${ }^{*}$ Dikutip dari Paul Arndt, Agama Orang Ngada: Kultus, Pesta dan Persembahan, hal 57-62.

The above example is a piece of traditional verse sung by Ngada people, including during rebaceremony. When Ngada people do reba party, Ngada people also dance while singing traditional verse poetry. In general, the custom verse that is sung contains a moral message. people who dance Ja'i / O Uwi as well as the people who watch the dance participated in living the traditional verses. The poem is not merely a complement to reba culture, but as a moral message to 
Ngada people to do good things as long as they live in the world.Besides being reba culture, it can be seen as an art in which it contains moral messages about life and the relationship between human and others, human with nature, and human with the ancestors, as well as human with God.In Cintamani magazine, Ida Wayan Oka Granoka (2002,50-52) quoted by (Geria, 2014: 45), declares 'art as rite'. The statement is in harmony with what the Ngada people do through reba that contains elements of art as well as sacred rites in celebration of gratitude to God and the ancestors.

\section{Conclusion}

Each tribe has a different culture, and that culture becomes its own characteristics and identity for certain ethnic groups. Nowadays, with the rapid development of modernization flow which is marked by technological progress and instant information of some culturecharacter begin to shift or adjust to technological development. Theefore, the authenticity of the culture slowly begins to fade from its shape, such as the society and the culture of reba that live in the midst of modernization.

Reba as a symbol and identity of Ngada people which until now still continue to defend and show its existence in the midst of modernization. The existence of reba does not stand alone, certainly based on Ngada's conscious attitude to keep preserving reba without being persistent by the current of modernization.Nevertheless modernization is still shared by Ngada people as an advancement for social change but not for cultural change in reba culture.It is caused of the reba that is a hereditary heritage of Ngada that reflects the identity of Ngada people. Reba can not be separated or mixed with pop culture, because basically reba is not only a ceremony but also reba as a sacred rite of Ngada people that contains various messages and values of Ngada people's life.

\section{References}

A.A. Gde Alit Geria (Volume 19, Nomor 1, 2014), Estetik dan Suci: Cermin Taksu Alami Bali. Jnana Budaya.

Arndt, P. (2007). Agama Orang Ngada: Kultus, Pesta dan Persembahan (Vol.II). Maumere: Candraditya.

Dhogo, C. (2009). Su'i Uwi: Ritus Budaya Ngada dalam Perbandingan dengan Perayaan Ekaristi. Maumere: Ledalero.

Iriani, (Volume 19, Nomor 1, 2013), Orang Bajo dan Kearifannya di Wakatobi. Jnana Budaya.

I Wayan Sudarma (Volume 20, Nomor 2, 2015), Tari Sanghyang Gandrung Tradisi Tari Sakral Masyarakat Sidetapa Kecamatan Banjar Kabupaten Buleleng. Jnana Budaya.

I Ketut Sudharma Putra (Vomume 19, Nomoer 2, 2014), Makna Tradisi Perang Api Di Pura Luhur Duasem Desa Subamia Kabupaten Tabanan. Jnana Budaya.

Kebudayaan, D. P. (1993). Kamus Besar Bahasa Indonesia. Jakarta: Balai Pustaka.

Lubis, M. (1993). Budaya Masyarakat dan Manusia Indonesia. Jakarta: Buku Obor.

Madjid, N. (1997). Islam Kemodernan, dan Keindonesiaan. Bandung: Mizam.

Poewardarminta. (2007). Kamus Umum Bahasa Indonesia Edisi Ketiga. Jakarta: Balai Pustaka.

Sugiyono. (2013). Memahami Penelitian Kualitatif. Bandung: Afabeta. 